\title{
PERANAN GURU PPKN DALAM MENGEMBANGKAN MODEL PEMBELAJARAN (BAHAN AJAR) ABAD 21 DI SMP NEGRI 2 KOTA TERNATE
}

\author{
Rustam Hasim¹, Sitirahia Hi. Umar ${ }^{1}$ \\ ${ }^{1}$ Dosen Program studi Pendidikan Pancasila dan Kewarganegaraan FKIP Unkhair
}

Email: rustamhasyim@gmail.com, sitirahia@yahoo.com

$\begin{array}{ll}\text { Diterima } & : 01-02-2019 \\ \text { Direvisi } & : 20-03-2019 \\ \text { Dipublikasi } & : 01-05-2019\end{array}$

\begin{abstract}
Abstrak. Penelitian ini bertujuan untuk menghasilkan perangkat pembelajaran pada mata Pelajaran Pendidikan Pancasila dan Kewarganegaraan (PPKn) yang berkualitas baik pada jenjang SMP, sehingga dapat meningkatkan hasil belajar siswa. Salah satu faktor yang memegang peranan penting dalam kegiatan belajar mengajar adalah perangkat pembelajaran. Tersedianya perangkat pembelajaran merupakan salah satu faktor yang menunjang proses pembelajaran berjalan dengan baik dan dapat meningkatkan mutu pendidikan. Perangkat pembelajaran adalah sejumlah bahan, alat, media, petunjuk dan pedoman yang akan digunakan dalam proses pembelajaran atau digunakan pada tahap tindakan dalam kegiatan belajar mengajar. Perangkat pembelajaran memberikan kemudahan dan dapat membantu guru dalam mempersiapkan dan melaksanakan kegiatan belajar mengajar di kelas. Hasil penelitian menunjukkan bahwa guru PPKn di SMP Negeri 2 Kota Ternate dalam melaksanakan perencanaan proses mengunakan perangkat pembelajaran meliputi silabus dan rencana pelaksanaan pembelajaran (RPP) yang memuat tujuan pembelajaran, materi ajar, metode pengajaran, sumber belajar, dan penilaian hasil belajar. Pengembangan perangkat pembelajaran dan bahan ajar di SMP Negeri 2 Kota Ternate adalah sebagai berikut: (1). Perangkat pembelajaran dan bahan ajar di SMP Negeri 2 Kota Ternate dalam menggunakan kurikulum K13. (2) Dalam pengembangan perangkat pembelajaran dan bahan ajar di SMP Negeri 2 Kota Ternate diawali dengan analisis materi pelajaran yang sesuai dengan standar dan kompotensi yang diharapkan pada perumuskan pengembangan perangkat pembelajaran yaitu (RPP) dan silabus.
\end{abstract}

Kata Kunci: Guru PPKn, pengembangan, bahan ajar, SMP Negeri 2 Kota Ternate.

\section{PENDAHULUAN}

Pendidikan adalah usaha sadar dan terencana untuk mewujudkan suasan belajar dan proses pembelajaran agar peserta didik secara aktif mengembangkan potensi dirinya untuk memiliki kekuatan spritual keagamaan, pengendalian diri, kepribadian, kecerdasan, akhlak mulia, serta keterampilan yang diperlukan dirinya, masyarakat, bangsa dan Negara (Djamarah, 2005). Dalam mewujudkan hal tersebut, maka diperlukan kompetensi pedagogik yang harus dimiliki seorang guru dalam merencanakan dan melaksanakan pembelajaran, merencanakan dan melaksanakan penilaian. Wujud nyata dari kompetensi tersebut adalah kemampuan guru untuk mengembangkan perangkat pembelajaran kemudian mengimplementasikannya di dalam proses belajar mengajar di kelas. Perangkat pembelajaran adalah salah satu wujud persiapan yang dilakukan oleh guru sebelum mereka melakukan proses pembelajaran. Persiapan mengajar merupakan salah satu tolok ukur dari sukses seorang guru. Kegagalan dalam perencanaaan sama saja dengan merencanakan kegagalan. Hal tersebut menyiratkan betapa pentingnya melakukan persiapan pembelajaran melalui pengembangan perangkat pembelajaran.

Peraturan Pemerintah (PP) Nomor 19 Tahun 2005 tentang Standar Nasional Pendidikan Pasal 20, "Perencanaan proses pembelajaran meliputi silabus dan rencana pelaksanaan pembelajaran (RPP) yang memuat sekurang-kurangnya tujuan pembelajaran, materi ajar, metode pengajaran, sumber belajar, dan 
penilaian hasil belajar. Sistem pendidikan nasional adalah keseluruhan komponen pendidikan yang saling terkait secara terpadu untuk mencapai tujuan pendidikan nasional. Pendidikan nasional adalah pendidikan yang berdasarkan pancasila dan Undang-Undang Dasar Negara Republik Indonesia Tahun 1945 yang berakar pada nilai-nilai, kebudayaan nasional Indonesia dan tanggap terhadap tuntutan zaman (Sisdiknas, 2003).

Dalam pembelajaran PKn, guru perlu memahami bagaimana menentukan model pembelajaran yang mampu mengembangkan pengetahuan dan wawasan kewarganegaraan (civic knowledge). Oleh karena itu penting bagaimana merancang pendekatan, strategi, metode maupun teknik yang dapat mengembangkan ranah kognitif siswa. Pengembangan civic knowledged dalam pembelajaran PKn menunjukan bahwa terdapat kaitan yang erat dan tidak terpisahkan dari dimensi civic skill khususnya dalam sub domain intelektual civic skill. Pada dasarnya, sumber belajar yang dipakai dalam pendidikan atau pelatihan adalah suatu sistem yang terdiri dan sekumpulan bahan atau situasi yang diciptakan dengan sengaja dan dibuat agar siswa belajar secara individual. Menurut Mulyasa (2006), bahwa pada hakekatnya tidak ada satupun sumber belajar yang dapat memenuhi segala macam kebutuhan, oleh karena itu bicara sumber belajar perlu dipandang dalam arti luas, jamak dan beraneka ragam. Menurut Martono (2005), ada beberapa peran sentral bahan ajar dalam memberdayakan siswa, yaitu; Bahan ajar dapat ditempatkan sebagai sumber informasi setelah guru, buku dapat menarik minat dan niat siswa untuk menguasai informasi dengan motivasi tinggi, bahan ajar dapat berperan sebagai manajer dalam kegiatan belajar siswa, bahan ajar dapat memenuhi tuntutan kurikulum dan memuat implementasi pesan kurikulum bahkan dapat melebihinya, bahan ajar dapat digunakan sebagai wacana untuk melatih daya nalar dan pembentukan sikap siswa untuk menghadai perubahan dunia yang relatif cepat., bahan ajar dapat memuat informasi yang esensial dan srtategis, bermanfaat sebagai alat pemecahan masalah dan bahan ajar dapat menyajikan informasi yang komunikatif, menarik dan tidak membosankan.

Pembelajaran dapat diartikan sebagai jalan yang digunakan oleh guru pembelajar untuk menciptakan suasana yang memungkinkan siswa belajar. Dalam pembelajaran Kurikulum 2013 (K-13) yang diberlakukan sekarang ini, pendidik terutama guru Pendidikan Kewarganegaraan dituntut untuk selalu kreatif dalam membuat dan menyusun silabus yang sesuai kondisi dan minat siswa. Selain itu guru juga harus inovatif dalam membuat media pembelajaran yang cocok untuk menjelaskan materi Pendidikan Kewarganegaraan. Karena terkadang perlu penjelasan yang lebih untuk memahami konsep dasarnya, sehingga materi tersebut mudah dipahami dan dimengerti oleh siswa maka guru harus menerangkan dengan menggunakan metode-metode yang di pahami oleh guru mata pelajaran agar mudah dipahami siswa tentang apa yang diajarkan tentang pendidikan kewarganegaraan.

Bahan ajar dapat juga menjadi media pembelajaran yang sangat berarti apabila bahan ajar tersebut digunakan sebagai alat komunikasi untuk membawa informasi akurat dari sumber belajar kepada pembelajar. Dengan bahan ajar yang baik, yang isinya mencakup Kompetensi Dasar (KD) sesuai dengan tuntutan standar isi, standar bahan ajar secara umum (penyajiannya menarik, bahasanya baku, illustasi tepat dan menarik) maka diharapkan proses pembelajaran yang dilakukan guru dan siswa mencapai hasil yang optimal. Beberapa faktor yang mempengaruhi kualitas bahan ajar, yaitu: (1) Sudut pandang; (2) Kejelasan konsep; (3) Relevan dengan kurikulum; (4) Menarik minat; (5) Membutuhkan motivasi; (6) Mentimulasi aktivitas siswa; (7) Ilustrasi; (8) Bahasanya sesuai dengan siswa; (9) Kalimatnya efektif; (10) Bahasa yang sopan, sederhana dan menarik; (13) Memantapkan nilai-nilai; (14) Selaras dan tidak bertentangan dengan Pancasila dan UUD 1945 serta peraturan perundang-undangan yang berlaku; dan (15) Tidak mengandung unsur yang dapat menimbulkan gangguan ketertiban yang berkaitan dengan suku, agama, dan ras (Mastutiningsih, 2003).

Kantor dinas pendidikan Kota Ternate merupakan salah satu organisasi/lembaga yang berkedudukan sebagai unsur pelaksana pemerintah daerah yang bertugas melaksanakan kewenangan otonomi daerah di bidang pendidikan dalam rangka tugas desentralisasi. Sebagai pelaksana, dinas pendidikan memeliki fungsi yang sangat strategis dalam mengelola penyelengaraan sistem pendidikan. Sehubungan dengan 
hal tersebut, kantor dinas pendidikan Kota Ternate dituntut untuk melasanakan manajemen sumberdaya manusia yang baik, sehingga dapat lebih meningkatkan kualitas dalam memberikan pelayanan kepada publik, terutama yang berhubungan dengan pendidikan di Kota Ternate.Untuk mewujudkan kinerja dinas pendidikan Kota Ternate yang baik dipengaruhi oleh banyak faktor, salah satunya adalah manajemen sumberdaya manusia (Rajaloa \& Hasim, 2018).

Kondisi keberadaan tenaga guru sebagaimana diuraikan di atas, dan dengan mempertimbangkan potensi sumberdaya manusia tersedia memperlihatkan perlu upaya nyata, berkesinambungan dan terpadu dari pemerintah daerah Kota Ternate, khususnya Dinas Pendidikan Nasional Kota Ternate. Dengan melalui biro kepegawaian (BKD) sebagai operasional kebijakan di bidang kepegawaian untuk melakukan rekrutmen dan pemerataan kebutuhan tenaga guru serta meningkatkan profesionalitasnya. Dengan harapan akan mampu menghasilkan sumberdaya manusia yang memeliki kualitas kinerja yang tinggi dan para guru yang mampu mengembangkan kapasitas yang lebih profesional. Apabila kebutuhan tenaga guru tersebut dapat dilaksanakan dengan tepat akan diperoleh manfaat yang besar bagi pemerintah Kota Ternate untuk meningkatkan sumberdaya manusia melalui peningkatan pendidikan didaerahnya (Rajaloa \& Hasim, 2018). Dengan demikian tulisan ini akan menjawab dua pertanyaan yaitu; (1) Bagaimana pengembangan perangkat pembelajaran dan bahan ajar di SMP Negeri 2 Kota Ternate? (2) Kendala-kendala apa saja yang dijumpai oleh guru-guru SMP Negeri 2 Kota Ternate dalam mengembangkan perangkat pembelajaran?

\section{METODE PENELITIAN}

Penelitian ini menggunakan pendekatan kualitatif naturalistik untuk dapat menggambarkan secara alami, lengkap, mendalam dan utuh mengenai pokok persoalan. Jenis penelitian ini kualitatif naturalistik, yang bermakna metode penelitian yang digunakan untuk meneliti pada kondisi obyektif alamiah. Pendekatan kualitatif yang digunakan dimaksudkan untuk memperoleh informasi dan penafsiran yang mendalam mengenai Peranan Guru PPKN dalam Mengembangkan Model Pembelajaran (bahan ajar) Abad 21 di SMP Negri 2 Kota Ternate, sesuai dengan realitas yang ada di lapangan, oleh karena itu pengumpulan data berdasarkan situasi yang wajar, langsung, dan apa adanya.

Lokasi penelitian di SMP Negri 2 Kota Ternate dengan pertimbangan antara lain dari segi kualitas, lokasi, dan presetasi para guru PPKn SMP Negeri 2 Kota Ternate. Dari 6 orang guru PPKn yang berprestasi, tersebut mendapat penghargaan dari Menteri Pendidikan Nasional sebagai guru berprestasi tingkat nasional.Penelitian ini di mulai pada bulan April hingga Juli 2019. Subjek penelitian atau sumber data dalam penelitian ini terdiri dari key informan dan informan. Dalam penelitian ini ditentukan Guru PPKn sebagai key informan. Sementara informan adalah para siswa SMPN 2 Kota Ternate. Penentuan subjek penelitian dilakukan dengan purposive, yaitu berdasarkan tujuan penelitian. Pengumpulan data dalam penelitian ini dilakukan melalui beberapa teknik, yaitu pengamatan, wawancara dan dokumentasi.

Norman Denzin \& Vonna Lincoln (2010) dalam (Soewarno, 1987), bahwa peneliti memiliki beberapa metode pengumuplan data yang meliputi, dokumentasi, observasi, dan wawancara.

1. Dokumentasi, merupakan suatu teknik pengumpulan data melalui bahan-bahan tertulis yang berkaitan dengan masalah penelitian. Peneliti memegang catatan harian, sejarah kehidupan cerita, biografi, peraturan, kebijakan, dan dokumen yang berbentuk gambar misalnya, foto, gambar hidup, sketsa, untuk mencatat hal-hal yang bersifat bebas atau belum ditentukan dalam daftar peneliti. Menurut (Sugiyono, 2012) dokumen merupakan catatan peristiwa yang sudah berlalu. Metode dokumentasi mempunyai keuntungan memperoleh data otentik yang lebih objektif untuk mendukung dan sebagai pelengkap dari angket dan wawancara. Disamping itu, dokumentasi juga tidak menggunakan bahan dengan biaya tinggi, dan memerlukan waktu yang banyak serta lebih efesien.

2. Observasi. Dalam penelitian ini peneliti mengobservasi tentang supervisi yang dilakukan pengawas sekolah dalam melakukan supervisi kelas, dalam meningkatakan profesionalisme dan kualitas guru 
dalam proses pembelajaran. Peneliti menggunakan teknik observasi (pengamatan) partisipatif, dimana sambil melakukan pengamatan, sekaligus peneliti juga ikut terlibat melakukan apa yang dikerjakan oleh sumber data. Observasi dilakukan dengan terjun langsung kelapangan secara aktif untuk memperoleh gambaran dan keterangan secara riil mengenai sikap dan prilaku instrumen. Keterangan informan yang diperoleh kemudian dianalisis, ditafsirkan, dan disimpulkan. Menurut (Arikunto, 2010) observasi yang paling efektif adalah melengkapinya dengan format atau blangko pengamatan sebagai instrumen. Format yang disusun berisi item-item tentang kejadian atau tingkah laku yang digambarkan akan terjadi.

3. Wawancara merupakan percakapan dengan maksud tertentu yang dilakukan oleh dua pihak, yakni pewawancara (interviewer) yang mengajukan pertanyaan dan terwawancara (interviewee) yang memberikan jawaban atas pertanyaan itu. Menurut (Arikunto, 2013) wawancara adalah pengadministrasian angket secara lisan dan langsung terhadap masing-masing anggota sample. Dalam penelitian ini, wawancara dilakukan secara bebas dan terkontrol, artinya wawancara dilakukan secara bebas sehingga diperoleh data yang luas dan mendalam. Dalam melakukan wawancara, peneliti menggunakan wawancara semi struktur dengan alasan bahwa peneliti bebas dan leluasa dalam mengajukan pertanyaan-pertanyaan tanpa terkait oleh suatu susunan pertanyaanpertanyaan yang telah disiapkan sebelumnya.

\section{Teknik Analisa Data}

Teknik analisa data lebih banyak dilakukan bersamaan dengan pengumpulan data. Untuk mengecek keabsahan data maka dilakukan beberapa hal, dab mencakup empat alur kegiatan yang secara bersamaan, yaitu: pengumpulan data, reduksi data, penyajian data, penarikan kesimpulan/verifikasi. Analisa data yang akan dilakukan peneliti berproses sejak merumuskan dan menjelaskan masalah, sebelum terjun ke lapangan, hingga penulisan hasil penelitian. Analisa data menurut Janice McDrury (Collaborative Group Analysis of Data, 1999) dalam Lexy J. Moleong, (2012) bahwa peneliti harus mempelajari data mengemukakan proses, dan komponen-komponen yang ada dalam satu analisa data berupa kata-kata kunci, model agar sumber datanya tetap dapat ditelusuri.

\section{PEMBAHASAN HASIL PENELITIAN}

\section{Pengembangan Media Pembelajaran PKn di SMP}

Pengembangan Pembelajaran PKn dalam Pembentukan Karakter Pengembangan pembelajaran Pendidikan Kewarganegaraan pada dasarnya harus memenuhi tiga aspek yaitu pengetahuan, keterampilan (skill), dan pembentukan karakter. Menurut Center for Civic Education pada (1944) dalam Nation Standard Civic and Government, ketiga komponen pokok tersebut ialah civic knowledge, civic skill, dan civic disposition (Sunarso, 2006). Dalam Pendidikan Kewarganegaraan paradigma baru dikatakan bahwa dalam pengembangan kecerdasan intelektual warga negara (civic intellegence) dimensi yang tercakup didalamnya seperti dimensi spiritual, rasional, emosional, sosiokultural dan tanggungjawab warga Negara (Zuriah, 2007). Nilai-nilai karakter tentu sangat penting dalam pengembangan PKn kedepannya.

Nilai-nilai karakter tersebut akan dapat diwujudkan apabila pengembangan pembelajaran Pendidikan Kewarganegaraan diorganisasikan dengan baik. Bahkan dikatakan tidak hanya mampu mewujudkan satu karakter saja, tetapi dengan pengorganisasian konten kurikulum dan pembelajaran Pendidikan Kewarganegaraan yang baik sangat dimungkinkan bahwa Pendidikan Kewarganegaraan akan menjadikan siswa sebagai manusia Indonesia yang berkualitas dan punya watak atau kepribadian terpuji, seperti agamis atau religius, transparan, jujur, disiplin, percaya diri, demokratis, kritis, cepat tanggap, modern dan tetap menjaga kemajemukan masyarakat dan bangsa Indonesia (Zuriah, 2007).

Ditegaskan bahwa pembentukan karakter bukanlah suatu pembelajaran bidang studi namun menjadi bagian yang terintegrasi dalam keutuhan proses pembelajaran khususnya Pendidikan Kewarganegaraan. 
Oleh karena itu, agar penginternalisasian nilai-nilai karakter dalam mata pelajaran pendidikan kewarganegaraan dapat terwujud secara efektif, maka perlu ditetapkan secara eksplisit essensial value, skills dan knowledge pada Standar Kompetensi dan Kompetensi Dasar. Oleh kerana itu, guru merupakan jabatan atau profesi yang memerlukan keahlian khusus sebagai guru. Pekerjaan ini tidak bisa dilakukan oleh orang yang tidak memiliki keahlian untuk melakukan kegiatan/pekerjaan sebagai guru. Tugas guru sebagai profesi meliputi mendidik, mengajar, dan melatih. Mendidik berarti meneruskan dan mengembangkan nilai-nilai luhur hidup. Mengajar berarti meneruskan dan mengembangkan ilmu pengetahuan dan teknologi, sedangkan melatih berarti mengembangkan keterampilan-keterampilan pada siswa (Yusuf \& Hasyim, 2016).

Oleh karenanya, pengembangan pendidikan kewarganegaraan yang terintegrasi dengan penginternalisasian nilai-nilai karakter memang seyogyanya diwujudkan secara nyata dalam kurikulum yang ada. Namun hal tersebut juga perlu didukung dengan penanaman nilai-nilai karakter secara implisit dalam suatu proses pembelajaran. Beberapa hal di atas sangatlah relevan dengan apa yang dikatakan dalam The Character Education Partnership (CEP) (Lickona, 2007) bahwa pembentukan karakter dikatakan sebagai bagian dari pendidikan nilai yang dilakukan melalui sekolah, dengan adanya suatu transformasi nilai-nilai yang akan diinternalisasikan dalam kegiatan sekolah maupun kegiatan di luar sekolah yang berguna dalam pengembangan karakter dalam siswa dalam berbagai hal. Pendapat di atas jelas memperkuat posisi Pendidikan Kewarganegaraan bahwa pendidikan nilai sebagai bagian integral dari Pendidikan Kewarganegaraan jelas memiliki dampak positif dalam pembentukan karakter siswa.

Dari paparan-paparan di atas, dapat dikatakan bahwa pembelajaran Pendidikan Kewarganegaraan mempunyai peran penting dalam pengembangan pembentukan karakter yang mana nilai-nilai karakter yang diwujudkan tidak hanya melalui civic knowledge namun juga civic skill dan civic disposition sebagai basis dalam mendorong sikap dan tindakan siswa menuju karakter yang baik. Oleh karena itu, perlu adanya faktor pendukung dalam pengembangan rancangan pembelajaran seperti silabus dan rencana pelaksanaan pembelajaran (RPP) yang diintegrasikan dengan pengembangan nilai-nilai keutamaan PKn. Sebagai contoh, pengembangan perumusan tujuan pembelajaran yang mengarah pada civic skiil dan pencapaian watak kewarganegaraan (civic disposition) perlu diperhatikan. Di sisi lain penentuan materi ajar yang meliputi materi jenis prinsip/proposisi dan materi jenis prosedur dan motorik guna pencapaian intelectual civic skill sangat menentukan keberhasilan terhadap dampak pembelajaran. Selain tujuan dan materi maka pemilihan model/pendekatan dan metode mengajar perlu dirancang dengan baik. Strategi atau metode tersebut ialah alternatif kegiatan yang dipilih oleh guru dalam rangka membantu siswa mencapai kompetensi yang diharapkan (Gafur, 2012).

Internalisasi nilai-nilai karakter dengan pengembangan secara eksplisit maupun implisit dalam kurikulum yang dilaksanakan oleh guru akan berhasil memberikan instructional effect dan nurturant effect apabila proses pelakasanaan pembelajaran dapat diwujudkan secara optimal. Evaluasi pembelajaran menjadi bagian penting sebagai ruang dalam memberikan kesempatan kepada siswa untuk memberikan koreksi terhadap efektivitas pembelajaran. Hal tersebut nantinya dapat membantu memberikan alternatif pembelajaran kepada siswa dalam rangka mendapatkan kenyamanan dalam pelaksanaan pembelajaran.

Bukan tidak mungkin, dengan kenyamanan tersebut akan mampu mendorong terwujudnya karakter yang baik bagi siswa. Evaluasi dalam hal ini bukan hanya penilaian formal terhadap kualitas RPP namun meliputi aspek pembelajaran yang dilakukan. Evaluasi ialah proses sistematis pengumpulan data atau informasi dengan tujuan untuk memberikan penilaian (judgement) yang dapat bersifat kuantitatif dan kualitatif. Dari definisi tersebut, sistem evaluasi atau sistem penilaian dimaksudkan sebagai proses sistematis pengumpulan data atau informasi baik yang berkenaan dengan proses maupun hasil pembelajaran untuk digunakan dalam memberikan penilaian. Berdasarkan uraian tersebut, kegiatan evaluasi merupakan salah satu komponen pembelajaran yang memegang peranan penting dalam pengembangan pembelajaran tidak terkecuali pembelajaran PKn. Tanpa melakukan kegiatan evaluasi maka tidak akan tahu ketercapaianpembelajaran siswa. Sehubungan dengan itu, para guru harus 
menguasai konsep dan sistem evaluasi pembelajaran termasuk evaluasi proses dan hasil dalam pembelajaran (Gafur: 2012). Evaluasi pembelajaran selain ditujukan pada hasil belajar, juga ditujukan pada proses belajar. Hal tersebut dilakukan agar terjadi kesinambungan guna memperoleh informasi yang lebih utuh (Muchson AR, 2012).

Pembelajaran merupakan suatu proses secara sistematis, artinya didalam pembelajaran terkandung beberapa komponen yang salingberkaitan dan mendukung untuk mencapai tujuan pembelajaran tertentu. Inti dari pembelajaran tidak lain adalah kegiatan belajar siswa dalam mencapai suatu tujuan pembelajaran. Belajar mengajar merupakan dua konsep yang tidak dapat dipisahkan antara satu dengan yang lainnya.

\section{Komponen-komponen Pembelajaran}

Dalam kegiatan pembelajaran memerlukan suatu proses perencanaan dan pengaturan secara seksama yaitu dengan mempertimbangkan beberapa komponen yang berpengaruh dalam kegiatan belajar mengajar agar dapat mencapai tujuan. Berikut adalah komponen pembelajaran diantaranya:
a. Guru
b. Peserta didik
c. Tujuan Pembelajaran
d. Materi Pembelajaran
e. Metode Pembelajaran
f. Media/alat
g. Evaluasi/penilaian

Pembelajaran pada hakikatnya merupakan suatu bentuk interaksi antara peserta didik dengan lingkungan belajar guna tercapainya tujuan pembelajaran (Sardiman A.M, 2011). Terdapat beberapa prinsip umum yang harus diperhatikan baik oleh pengajar maupun peserta didik agar pembelajaran bisa terlaksana dengan efektif serta mencapai tujuan yang diharapkan. Menurut (Slameto, 2010) mengemukakan beberapa prinsip umum dalam pembelajaran sebagai berikut:

1 Bahwa belajar menghasilkan perubahan perilaku peserta didik yang relatif permanen;

2 Peserta didik memiliki potensi, gandrung dan kemampuan yang merupakan benih kodrati untuk ditumbuhkembangkan;

3 Perubahan atau pencapaian kualitas ideal itu tidak tumbuh alami liner sejalan proses kehidupan.

Inovasi adalah suatu usaha untuk memperkenalkan ide, barang, produk, metode atau apapun yang sifatnya baru. Inovasi juga dapat diartikan sebagai modifikasi/perbaikan dari produk yang telah ada sebelumnya. Tetapi, hasil dari perbaikan itu tetap disebut sebagai sesuatu yang baru. Proses berinovasi melibatkan daya kreatifitas pembuatnya. Tujuan dari inovasi adalah untuk memecahkan persoalan yang terjadi pada produk, metode atau cara-cara sebelumnya. Inovasi juga bertujuan untuk meningkatkan aspek efisiensi dan efektivitas. Inovasi dalam bidang pendidikan bisa dilakukan di berbagai aspek/tingkatan, seperti dalam hal manajemen pendidikan, metodologi pengajaran, media pembelajaran, sumber belajar, pelatihan guru, implementasi kurikulum, pembelajaran dan sebagai berikut:

1. Memiliki ciri atau unsur kebaruan; Sebuah inovasi haruslah berupa suatu hasil karya/pemikiran yang baru dan orisinil.

2. Program inovasi dilakukan melalui program yang terencana; Suatu program inovasi tidak boleh dilakukan melalui suatu proses yang tergesa-gesa. Sebuah program inovasi haruslah dipersiapkan secara matang dengan program yang jelas dan terencana.

3. Program inovasi digulirkan dengan sebuah tujuan; Tujuan yang ingin dicapai melalui penerapan suatu program inovasi harus tertulis dengan jelas di dalam naskah 
perencanaannya, termasuk arah dan strategi yang akan ditempuh demi mencapai tujuan tersebut.

Suhadi, (2007) mengemukakan bahwa "Perangkat pembelajaran adalah sejumlah bahan, alat, media, petunjuk dan pedoman yang akan digunakan dalam proses pembelajaran". Dari uraian tersebut dapatlah dikemukakan bahwa perangkat pembelajaran adalah sekumpulan media atau sarana yang digunakan oleh guru dan siswa dalam proses pembelajaran di kelas, serangkaian perangkat pembelajaran yang harus dipersiapkan seorang guru dalam menghadapi pembelajaran di kelas, berikut dalam tulisan ini kami membatasi perangkat pembelajaran hanya pada: (a) Rencana pelaksanaan Pembelajaran (RPP), Buku siswa (BS), Buku Pegangan Guru (BPG), Lembar Kegiatan Siswa (LKS), dan Tes Hasil Belajar. Oleh karena itu, Guru merupakan faktor yang sangat dominan dan paling penting dalam pendidikan formal pada umumnya karena bagi peserta didik, guru sering dijadikan tokoh teladan, bahkan menjadi tokoh identifikasi diri. Oleh sebab itu, guru seyogyanya memiliki perilaku dan kemampuan yang memadai untuk mengembangkan siswanya secara utuh. Kenyataan dilapangan menunjukan bahwa performance (unjuk kerja) guru didalam melaksanakan kegiatan belajar mengajar (KBM) sangat bervariasi dan kualifikasi keguruannya beraneka ragam (Hayun \& Hasyim, 2018).

\section{Peningkatan Pengembangan Pembelajaran PKn}

Pengembangan pembelajaran Pendidikan Kewarganegaraan pada dasarnya harus memenuhi tiga aspek yaitu pengetahuan, ketrampilan ( skill), dan pembentukan karakter. Menurut Center for Civic Education pada (1944) dalam Nation Standar Civic and Government, ketiga komponen pokok tersebut ialah civic knowledge, civic skill, dan civic disposition (Sunarso, 2006).

Pengembangan pembelajaran PKn dalam mendorong pembentukan karakter pada siswa dapat dilihat melalui tiga proses yaitu pengembangan perencanaan pembelajaran, pelaksanaan pembelajaran dan evaluasi pembelajaran yang mencakup evaluasi hasil dan proses. Namun di sisi lain, dapat dilihat pula pengembangan kegiatan yang ada di sekolah yang mempengaruhi pula pembentukan karakter siswa. Oleh karena itu, tujuan pendidikan adalah untuk memajukan budi pekerti sehingga seorang individu menjadi manusia yang berbudi pekerti luhur dan mampu mencapai kesempurnaan hidup sehingga mampu hidup selaras dengan alam dan masyarakatnya (Yusuf \& Hasyim, 2016).

Pengembangan pembelajaran PKn dalam mendorong pembentukan karakter pada siswa dapat dilihat melalui tiga proses yaitu pengembangan perencanaan pembelajaran, pelaksanaan pembelajaran dan evaluasi pembelajaran yang mencakup evaluasi hasil dan proses. Namun di sisi lain, dapat dilihat pula pengembangan kegiatan yang ada di sekolah yang mempengaruhi pula pembentukan karakter siswa. Berikut ini akan diuraikan mengenai pengembangan pembelajaran PKn, yakni perencanaan pembelajaran PKn dalam rangka pengembangan pembelajaran, salah satu tugas pendidik adalah menyusun perencanaan pembelajaran sebagai pedoman atau landasan tertulis dalam melaksanakan kegiatan pembelajaran yang dibedakan menjadi dua yaitu silabus dan rencana pelaksanaan pembelajaran (RPP). Hasil analisis data yang ada menunjukan bahwa terdapat pengembangan nilai-nilai karakter dalam pengembangan perencanaan pembelajaran baik di SMP Negeri 2 Kota Ternate sesuai dengan konteks materi yang diajarkan.

Nilai-nilai yang dikembangkan guru dalam perencanaan pembelajaran melalui silabus dan dikembangkan melalui RPP membuktikan bahwa adanya keseriusan dalam mendorong pembentukan sikap dan kepribadian siswa. Pengembangan yang diinginkan tidak hanya diwujudkan melalui indikator pencapaian kompetensi saja namun juga mencakup strategi pembelajaran yang ada dalam perencanaan pembelajaran PKn dengan menyisipkan aspek life skill.

Pelaksanaan pembelajaran PKn merupakan inti dari kegiatan pembelajaran yang sesungguhnya. Pengembangan pelaksanaan pembelajaran PKn yang dilakukan oleh guru dengan menggunakan 
metode/pendekatan yang variatif mampu memberikan dampak positif pada perilaku siswa pada saat pembelajaran. Dengan begitu, guru tidak sekedar melakukan kegiatan transfer pengetahuan saja namun juga melakukan transform perilaku. Penanaman dan pengintegrasian nilai-nilai karakter yang dikembangkan oleh guru seperti sikap kedisiplinan, sikap kritis, tanggung jawab dan karakter lainnya perlahan mulai terlihat efektif pada saat pembelajaran.

\section{Evaluasi Pembelajaran PKn di SMP}

Evaluasi ialah proses sistematis pengumpulan data atau informasi dengan tujuan untuk memberikan penilaian (judgement) yang dapat bersifat kuantitatif dan kualitatif (Nurkancana \& Sumartana, 1986). Dari definisi tersebut, sistem evaluasi atau sistem penilaian dimaksudkan sebagai proses sistematis pengumpulan data atau informasi baik yang berkenaan dengan proses maupun hasil pembelajaran untuk digunakan dalam memberikan penilaian. Berdasarkan uraian tersebut, kegiatan evaluasi merupakan salah satu komponen pembelajaran yang memegang peranan penting dalam pengembangan pembelajaran tidak terkecuali pembelajaran PKn. Dalam rangka lebih memperkuat pelaksanaan pendidikan karakter pada satuan pendidikan telah teridentifikasi 18 nilai yang bersumber dari agama, Pancasila, budaya, dan tujuan pendidikan nasional, yaitu: religius, jujur, toleransi, disiplin, kerja keras, kreatif, mandiri, demokratis, rasa ingin tahu, semangat kebangsaan, cinta tanah air, menghargai prestasi, bersahabat/komunikatif, cinta damai, gemar membaca, peduli lingkungan, peduli sosial, tanggung jawab (Kemdiknas, 2011).

Kegiatan evaluasi pembelajaran semata-mata tidak hanya dilakukan dengan tes tertulis namun juga dilakukan secara lisan dengan metode tanya jawab. Di sisi lain, aspek penilaian atau kegiatan evaluasi pembelajaran yang dilakukan oleh guru yang dimuat dalam suatu tabel penilaian telah memasukan unsur-unsur kedisiplinan, kemampuan bekerjasama, kemampuan menghargai orang lain serta kemampuan menyampaikan pendapat. Penilaian pembelajaran dilakukan juga melalui penugasan. Penugasan menjadi stimulus bagi para siswa dalam penanaman nilai-nilai kedisiplinan, ketertiban dan tanggung jawab secara individual yakni dengan pemberian deadline pengumpulan tugas. Bagi yang mengumpulkan terlebih dulu guru memberikan kredit poin atau tambahan nilai sebagai reward terhadap mereka yang disiplin.

Oleh karena itu, kegiatan evaluasi yang dilakukan guru PKn di SMP negeri 2 Kota Ternate telah menggunakan penilaian hasil dan proses yang memberikan dampak positif bagi peserta didik. Hal ini sejalan dengan pendapat (Nurkancana \& Sumartana, 1986), indikator-indikator yang ada dalam hasil penelitian telah sesuai dengan kegiatan perencanaan, pelaksanaan maupun kegiatan evaluasi pembelajaran menunjukkan adanya stimulus yang mampu mendorong pembentukan karakter pada siswa. Karakter yang tercermin oleh siswa di SMP Negeri 2 Kota Ternate berdasarkan kegiatan pengembangan pembelajaran PKn yaitu adanya sikap religius yang ditunjukkan dengan setiap mengawali dan mengakhiri kegiatan pembelajaran peserta didik melakukan kegiatan doa, siswa-siswi dengan memberikan senyum, sapa, salam dan menunjukkan sopan dan santun saat bertemu di dalam kelas maupun di luar kelas.

Dalam pembelajaran PKn, guru perlu memahami bagaimana menentukan model pembelajaran yang mampu mengembangkan pengetahuan dan wawasan kewarganegaraan (civic knowledge). Oleh karena itu penting bagaimana merancang pendekatan, strategi, metode maupun teknik yang dapat mengembangkan ranah kognitif siswa. Pengembangan civic knowledgedalam pembelajaran PKn menunjukan bahwa terdapat kaitan yang erat dan tidak terpisahkan dari dimensi civic skill khususnya dalam sub domain intelektual civic skill.

Terdapat juga sikap disiplin dan tanggung jawab ditunjukan siswa kala mendapatkan tugas dari guru mereka mengumpulkan sesuai deadline yang ditentukan, tidak ada siswa yang terlambat saat mengikuti kegiatan pembelajaran; sikapjujur ditunjukan oleh siswa pada saat mengerjakan ulangan susulan maupun ulangan harian yaitu mereka tidak mencontek. Sikap kritis juga ditunjukan oleh siswa saat guru 
menjelaskan mengenai berita-berita aktual sehingga memunculkan beberapa pertanyaan oleh siswa. Di sisi lain, siswa juga menghargai keberagaman yang ditunjukan dengan sikap saling menghargai baik di dalam kelas maupun di luar kelas, latar belakang siswa yang sangat beragam tidak lantas bagi mereka untuk saling mengejek satu sama lain sebagai contoh ketika temannya yang berasal dari Maluku Utara menjawab pertanyaan dari guru mereka tetap memberikan apresiasi, dan sebagainya.

\section{KESIMPULAN}

Berdasarkan hasil penelitian di SMP Negeri 2 Kota Ternate, siswa kurang aktif dalam kegiatan belajarmengajar. Siswa cenderung tidak begitu tertarik dengan pelajaran Pendidikan Kewarganegaraan karena selama ini pelajaran pendidikan kewarganegaraan dianggap sebagai pelajaran yang hanya mementingkan hafalan semata, kurang menekankan aspek penalaran sehingga menyebabkan rendahnya minat belajar pendidikan kewarganegaraan siswa di sekolah. Peranan dan tanggung jawab guru dalam pembelajaran semakin kompleks, karena peran guru dalam proses pembelajaran menempati posisi yang sangat strategis. Guru harus lebih dinamis dan kreatif dalam mengembangkan proses pembelajaran bagi peserta didik. Dalam pembelajaran guru harus senantiasa melakukan berbagai peningkatan pembelajaran dan mengembangkan model pembelajaran yang tepat sesuai pada mata pelajarannya.

Masalah utama dalam pembelajaran Pendidikan Kewarganegaraan ialah peranan dan cara guru secara tepat dalam meningkatkan keaktifan siswa pada saat penyampaian materi pelajaran Pendidikan Kewarganegaraan.Pengembangan pembelajaran PKn dalam mendorong pembentukan karakter siswa dapat dilihat melalui tiga proses penting yaitupengembangan perencanaan pembelajaran melalui Silabus dan RPP, pelaksanaan pembelajaran dengan berbagai pendekatan, dan evaluasi pembelajaran yang mencakup evaluasi proses dan hasil.

Seorang guru dalam menyampaikan materi perlu memilih model pembelajaran yang sesuai dengan keadaan kelas atau siswa sehingga siswa merasa tertarik untuk mengikuti pelajaran yang diajarkan. Mata pelajaran pendidikan kewarganegaraan merupakan mata pelajaran yang memfokuskan pada pembentukan diri. Untuk itu peranan guru pendidikan kewarganegaraan tidak hanya menyampaikan materi secara lisan atau ceramah saja tetapi harus memilih model pembelajaran yang dapat meningkatkan keaktifan siswa pada pembelajaran pendidikan kewarganegaraan.

\section{DAFTAR PUSTAKA}

Arikunto. (2010). Prosedur Penelitian Suatu Pendekatan Praktik. In Rineka Cipta. https://doi.org/10.1016/j.minpro.2005.02.005 Arikunto, S. (2013). Metodologi Penelitian, Suatu Pengantar Pendidikan. In Rineka Cipta, Jakarta. Jakarta: Rineka Cipta.

Djamarah, S. (2005). Psikologi Belajar. In PT. Rineka Cipta.

Hayun, S., \& Hasyim, R. (2018). MANAJEMEN KOMPETENSI GURU NEGERI OLEH DINAS PENDIDIKAN KABUPATEN HALMAHERA TIMUR. GeoCivic, 1(1), 14-25.

Nurkancana, W., \& Sumartana, P. P. N. (1986). Evaluasi Pendidikan. In Surabaya: Usaha Nasional.

Rajaloa, N. I., \& Hasim, R. (2018). Manajemen Perencanaan dan Rekrutmen Tenaga Pendidik Oleh Dinas Pendidikan Kota Ternate. EDUKASI, 16(1), 11-28.

Sardiman A.M. (2011). Interaksi dan Motivasi Belajar Mengajar. In Book. https://doi.org/10.1016/j.bjps.2007.11.059

Slameto. (2010). Belajar dan Faktor-Faktor yang Mempengaruhi. Jakarta: Rine.

Soewarno, B. (1987). Metode Kuantitatif dalam Penelitian Ilmu-Ilmu Sosial dan Pendidikan. In Jakarta: Depdikbud.

Sugiyono. (2012). Metode Penelitian Kuantitatif, Kualitatif Dan R\&D. Bandung: Alfabeta, p. 361. https://doi.org/10.1017/CBO9781107415324.004

Sunarso, S. (2006). Membangun Masyarakat Demokratis yang bermoral lewat Pendidikan Kewarganegaraan. Jurnal Civics: Media Kajian Kewarganegaraan, 3(1).

Yusuf, M., \& Hasyim, R. (2016). Peranan Guru dalam Membangun Kesadaran Cinta Tanah Air Pada Siswa Sekolah Dasar (Telaah Teoritik). Pedagogik, 4(1), 8-16.

Zuriah, N. (2007). Pendidikan Moral \& Budi Pekerti dalam Perspektif Perubahan. In PT. Bumi Aksara. 